\title{
THE EUROPEAN UNION'S CULTURAL POLICY: THE NEW TASKS?
}

Europe's destiny resides in the sphere of 'spirit and the intellect'

G. Steiner (Steiner, 2004: 32)

The debate over European cultural policy has been conducted in various forums. It's aim is still unknown. Topics taken up during the European debates are usually of a general nature and are only an introduction to critical reflection on what European culture is today. Even if the answer seems obvious that it is made up of the cultures of the Member States, we still do not know what it should be called. "High culture", remaining in elite circles of interest, or so. "Pop culture"? Perhaps the answer is indirect, and refers to the culture that we do not know from the media, the internet, billboards and banner ads, but rather that which we know through membership in a particular social group, religious community and, most of all, family.

While facing the social, culture and technological changes, in the epoch of digital convergence, and during economic crisis, the European Union must be ready for another step in the redefinition of its goals, to define the needs of protection of every aspect of the community's life. Those needs are connected with the necessity to re-check policies of identity, with the main goal being to boost particular and collective national identities. The law of "cultural belonging" is one of the basic characteristics of every human being. For that reason national culture is particularly well guarded in European regulations. Regulatory policy is only basic in how it protects cultural pluralism in Europe, however every action that makes up a culture is the point of interest for each particular EU Member State (Chałubińska-Jentkiewicz, 2013: 38-56).

Regulating culture itself is not a EU competency. It comes out of the fear of danger for national identity (religious and national). This is a unique dilemma in times of refugees to Europe. According to B. Kerremans: "Culture is the result of identity, according to the identity of the legitimacy of sovereignty" (Dragicevic-Sesić, Stojkovic, 2010: 198).

The definition of national culture includes language, traditions, legacy and a need for identity. That is why the UE regulation of culture would spawn conflict and tension between and among the Member States. In the epoch of digital communication, particular cultures rub against and influence each other as never before. The cooperation of cultures is usually based on the EU Member States' strategies. The unique form of cooperation comprises important events organized as part of the "EU Member State presidency in European Council". The debate offers an opportunity for every country leader 
to fulfill his image strategies for the broader the European audience. It comes down to the fact that the national culture is an image profile of every European society, and the activity in animation of cultural events, participating in debates, are the way of focusing Europe's attention on important - in terms of particular society - topics, key phenomena, and important processes.

Strategies concerning cultural policy are relating directly to definition of cultural protectionism, which in light of advances in telecommunications is gaining a totally new meaning. Cultural protectionism contains problematic aspects regarding the progress of cultural "industries" (along with the European audiovisual industries advances, and with consideration of regulations relating to the telecommunications market), access to the national legacy, creating the European cultural space and protection of intellectual property.

For the sake of range of the considering problem, the European cultural regulations should have been brought up. The analysis of the legal framework comes near the characteristics of strategy and goals of the EU in subject of culture. At the same time this is a background for cultural activities. The present social and political determinants are important elements in judging these events. In their context we should judge the subject of debates and discussions taken on during future events connected with this theme.

\section{LEGAL FRAMEWORKS}

Culture and national identity are a part of line of progression of every society and are the ground for its participation in a bigger society, determined by processes of $\mathrm{glob}$ alization (Chałubińska-Jentkiewicz, 2011: 45). According to Article VI of the Treaty on the Functioning of the European Union: "The Union shall have competence to carry out actions to support, coordinate or supplement the actions of the Member States. The areas of such action shall, at European level, be: (a) protection and improvement of human health; (b) industry; (c) culture; (d) tourism; (e) education, vocational training, youth and sport."

The European cultural policy top a certain extent is only an elaborated system of regulations, containing legislation in a socio-economic context. One example is regulation regarding audiovisual policy. However this area, because of its particular nature, goes beyond activities associated with a strict definition of strict "culture". Harmonization in cultural policy comes down to the European programs that support cooperation and cultural exchange. It is validated by the fact that the biggest cultural value of Europe is its plurality. This attribute is most frequently brought up in every kind of European document associated with this area.

According to P. Kern: "EU policy should not ignore the problems of national and regional cultures. This is a breeding ground for national resentments, important in the eyes of European citizens. Europe is primarily a cultural space composed of many different cultures. This is her chance in the world to appreciate that originality and diversity" (Kern, 2011: 62). This concept is the basis of cultural policy of EU as it affects progress in telecommunications and, in conditions of social changes related to the financial crisis and, finally, in situation of solidification of national countries. These ten- 
dencies cause a dodge around harmonization, but according to TFUE there cannot really be any normative harmonization. The $\mathrm{EU}$ is contributing to cultural progress of Member States and fostering respect for both national and regional plurality while simultaneously pointing out the meaning of a common cultural legacy (The Treaty, 2007: Art. 167). The Union's efforts come down to encouraging cooperation between and among Member States and, if necessary, to assisting and complementing their activities in following domains:

- deepening the knowledge and spreading the culture and history of European nations:

- saving and protecting cultural legacies;

- non-trade cultural exchanges;

- arts and literature, including audiovisual matter.

The European Union and Member States are supporting the cooperation with other countries and international organizations that are specified in the field of culture. This is especially so with respect to the activities of the European Council. In order to fulfill the statements above there are two basic instruments:

- the European Parliament and Council, which according to the regular legislative procedure and after consultation with regional committees, approve encouraging projects - with exception of any type of harmonization of statutory or executive provisions of Member States:

- the Council is acting at the behest of the Commission.

Moreover, in the Charter of Fundamental Rights of the European Union (O.J. UE C 83, 30.03.2010), in Article 22 the basic rule is that the Union respects cultural, religious and linguistic plurality. The necessity of protection of cultural identity is strictly connected with the stepped-up process of the European integration, often followed by feelings of threat by national countries. The fear of further the European integration is based on the nation's ability to ensure its survival. Nations will let integration happen only if they are positive that their identities are not at risk, even though it may be strengthened through relation with other identities.

According to $\mathrm{O}$. Weaver, if the nation feels it can survive only by remaining sovereign and independent, if it believes the nation may become integrated via a situation in which its culture is only reproduced, it will block further integration (Weaver, 1995: 42-43). Cultural differences are not the only source of conflicts as institutionalization and states' interconnections also lead to discord. In these conditions cultural "goods" tend to be highly protected both by countries and by individuals. Cultural protectionism is becoming a totally separate category from broader national protectionism (Kitler, Skrabacz, 2010: 51). It results from the fact that the state's basic task is taking care of existence and progressiveness of the nation as constitutional authority. That is how the role of culture was defined in basic laws in the Constitution of the Republic of Poland of 2 April, 1997. According to the Article VI, Act 1 of the Polish Constitution, Poland is creating a certain climate for spreading culture and creating equal access to the "goods" of culture as a source of identity for the nation and its progress (Zeidler, 2004: 346; Krzemień-Ojak, 1991: 4-6). The definition of cultural "goods" as identified by Polish constitutional law includes all of the elements based in national cultural legacy. 


\section{STRATEGY}

In the certain legal positions mentioned above, it is possible for new strategies and European programs concerning mutual actions in the field of culture to rise. One of the strategies is defined in the European Council's motions concerning the culture of regions. This document addresses the concept of ongoing change, economic crises, social relationships, ethics, politics and culture, reflecting apathy, pessimism and cultural indifference. In such conditions changes seem necessary, including "metropolization" and local progress, treating regions as privileged partners on the way to cultural advancement (decentralization of culture, its unique character connected with tradition and history of particular regions), cultural democracy, which primary deals with man, his creativity and knowledge, including media, entertainment and technology, engaging animators of culture, whose main task is improving communication between the systems.

In November 16, 2007 resolution of the European Council concerning the European plan of action in the name of culture, it is pointed out that culture and its specific attributes, including plurality of language, are the key elements of the process of the European integration (O.J. EU C 287.1, 29.11.2007). This is based on mutual values and respect for nations' mutual legacies, and aims to propagate cultural plurality and a sharing role for culture. In the resolution the main goals are strictly determined, for example:

a) propagating cultural plurality and multi-cultural dialogue;

b) propagating culture as catalyst for employment, innovation and competition;

c) propagating culture as an important element of international relationships within the Union.

In the field of actions in the name of plurality it was found necessary to:

a) encourage artists and other people working in the field of culture toward mobility;

b) promote cultural legacy, especially by moving exhibitions and by supporting the process of digitization, keeping in mind improvement made possible by giving access to different cultures and languages:

c) promote cross-cultural dialogue as way of contributing to creating of the European identity, the European citizenship, and social cohesion, thanks to, for example, progression of multicultural competencies among the EU citizens.

In the range of propagating culture as a catalyst of creativity, the following actions should be taken:

a) propagating better use of mutual relationships between culture and education, especially through the support of artistic education and participation in cultural activities, keeping in mind progress of creativity and innovation;

b) providing possibilities for business education for active in the field of culture and creation:

c) creating an environment that fosters progress of various branches of culture, including the audiovisual field, which will increase of potential of those branches, especially small and big businesses, and providing stimulus for creation of creative partnerships among various cultural and other sectors - all in the context of local and regional progress as well. 
On the other hand, in range of propagating culture as an important element of the EU international relationships, the following actions are necessary:

a) strengthening the role of culture in the EU's international relationships and its policy of progress;

b) promoting UNESCO conventions in the name of protecting and promoting plurality in cultural expression and committing to its propagation on an international level;

c) propagating multicultural dialogue and interaction between citizen the Member States and other countries;

d) encouraging the cooperation between the Member States' cultural institutions.

In the resolution it is pointed out that actions that are being taken to achieve those goals should give Europe new values and should be realized with full respect to the rule of national sovereignty. Implications on the EU level are not excluding the Member States their own political goals on the national level. It points out as well, that these goals should be treated as elastic frameworks, which are supposed to direct future actions in the field of culture. In this case the decision number 1983/2006/WE the European Parliament and the Council in case of European Year of Multicultural Dialogue (O.J. UE L 412, 30.12.2006) should be brought up, in which it is pointed out that one of the main projects of the European integration is finding ways to lead multicultural dialogue and dialogue between citizens as a way to increase respect for cultural plurality and to enable functioning in complex reality of European societies, considering different cultural identities and beliefs. For multicultural dialogue it is important to keep the input of different cultures of the Member States. This highlights that culture and multicultural dialogue are the keys for the study of harmonized existence. The decision defines the tools to realize these goals. In these tools we can find for example: get-togethers and initiatives on the European level, aiming for propagation of multicultural dialogue by direct participation or access to the biggest possible number of people. The July 19, 2010 Commission Report on multicultural dialogue, for the European Parliament and Council, and for the European Social and Economy Committee of Regions $(\operatorname{COM}(2010) 390$ final), sets forth the European agenda for culture. The report defines the position of culture in the Union's policy. According to this document: "Culture is a foundation of the European project and is the ground on which the European Union's 'unity in plurality' is based. Respect for mutual values leads to peace, stability and unity in the European Union. In the process of globalization culture may be, in a special way, an aid in the realization of the European strategy via intelligent and balanced progress supporting society's acceptance, supporting stability, mutual understanding and cooperation all around the globe" (Commission Report, 2010). This document defines the input of particular Member States in activities connected with culture. The Commission has also suggested a few new work methods, in particular an open method of coordination and highly organized dialogue within the sphere of culture. In the Council's work schedule for 2008-2010, four groups of experts were established for exchanging experience and creating orders concerning priority subjects:

- enterprises from cultural and creative branches;

- synergy of culture and education;

- mobility of artists and other people professionally working in the field of culture. 
On the other hand, in the Council's conclusions and based on the Member States' discussions of the work schedule for 2011-2014 (O.J. UE C 325, 2.12.2010), it was noted that culture can be the cause for realization of strategy goals in the name of intellectual and balanced progress supporting social acceptance. "Europe 2020" defined six goals of progressive tasks:

- Priority A: cultural plurality, multicultural dialogue and ease of access, supporting social acceptance;

- Priority B: cultural and creative enterprises;

- Priority C: ability and mobility;

- Priority D: cultural legacy, including mobility of museum assets;

- Priority E: culture in the context of external relationships;

- Priority F: cultural statistics.

At the same time the document defines directives. One of the goals in the EU politics is giving the Member States the proper initiatives in other fields of the Commission's and the Council's activities which have influence on culture, organizing Ministry of Culture officials meetings in order to discuss and use the results gained, organizing informal meetings of Ministry of Culture officials and officials responsible for culture in Ministries of Foreign Affairs, in order to develop strategic approaches to culture in light of external relationships, and in order to strengthen cooperation in this area. The "Europe 2020" strategy proposed by the European Commission aims to lead Europe back on track to long-term progress with help from sources used to propagate social acceptance. According to this proposition, culture can play a big role through such projects as: "Union of innovation" (creative ecology, non-technical innovations); "Digital Agenda" (media usage, new surroundings for creation and access to culture); and "New abilities in new work places" (multicultural competencies and crossover abilities). The goal is to strengthen the role of culture regionally and locally by promoting unity in policymaking. On the other hand, in countries from outside of the EU, the me policies for spreading external relationships is strictly connected with the goal to establish Europe as the best place for creation by propagating balanced cultural exchange and cooperation with the rest of the world. The aims of the European Union, as expressed in the goals for such agreements, are connected with propagating cultural plurality of European nations, and are characterized by the strategic goals of the Union in the field of culture. Multicultural dialogue and pluralism are the hallmarks for the actions of national countries on the European level. The Union's rules considering organization of Unions activities are consistent with these goals.

\section{CULTURAL AIMS IN THE EU}

Holding leadership in the decision-making center of the Union, (i.e. the European Union Council) offers a special opportunity for every Member State. The half-year leadership tenure makes the Member State the most important in the Union, giving it influence over the creation of the most important EU's goals in the field of cultural policy, formal frameworks and informal meetings - on the highest level. This way, a particular country participates in ensuring effectiveness and realization of the European Union's 
policy. Preparing and holding the discussion is strictly attached to organization for exchanging opinions in difficult cases. This type of exchange includes multicultural dialogue and realization of the leadership's goals in with respect to culture. During Poland's leadership in the European Union's Council, the main idea of Country Cultural Program of Presidency 2011 was "Art for Social Change", stressing culture as the tool for change. Art for Social Change defined artistic activities as a way of changing social consciousness. The mainstream of modern art mentioned above is supposed to force change through supporting innovation and critical thinking. Many cultural institutions promoting polish culture in European Union were involved.

According to motions from President of Ministry Council's Advisors Team "Poland 2030", the Minister of Culture and National Legacy, the National Audiovisual Institute (NInA) developed and realized the National Program of Polish Cultural Presidency 2011, and the Institute of Adam Mickiewicz developed the international Program of Polish Cultural Presidency 2011's events. ${ }^{1}$. Under this program, many meetings and events were staged to explain the ideas of the Eastern Partnership program. The Foreign Program of Polish Cultural Presidency 2011 operated under the motto "I, CULTURE". Both areas of action, national and foreign, completed key tasks under the Ministry of Culture and National Heritage. Even though the Polish presidency was during an economic crisis, Polish presentations were seen across the Union by more than 19 million people. Activities included more than 400 events organized in 10 capitals - Brussels, Berlin, London, Paris, Madrid, Moscow, Kiev, Minsk, Tokyo, and Beijing. The program realized was thanks to cooperation with foreign partners, Polish cultural institutions and Ministry of Foreign Affaires - embassies and consuls. At the same time Poland prepared more than 1,000 art projects, in which more than 170 partnership organizations and national cultural institutions participated (Cultural Programme, 2011). These projects were realized in cooperation with local non-governmental organizations and the European partners. The first idea was that through creative activity, seeing yourself and your own activity in the wider context, you could treat culture and art as values, rooted in the real world and taking on discussion with them. Under this assumption, organization of the national program was held by different non-governmental institutions and territorial self-governments.

\section{CULTURE V. IDENTITY: CULTURAL SAFETY}

Activities by the Member States in the area of culture grows along with the growth of cultural enterprises and the convergence of services in the field of digital communication. As mentioned, the EU policy covers problematic cultural aspects of national countries insomuch as those problems bring up a subject common to all markets. It concerns, in particular, problems connected with intellectual property protection, which covers for example problematic aspects of competition, which is the basic rule of the European regulations.

1 See: Krajowy Program Kulturalny Polskiej Prezydencji (2011), http://www.nina.gov.p1/projekty/krajowy-program-kulturalny-polskiej-prezydencji-2011/ (6.12.2015). 
Progress of creative enterprises, which in a big way influences economic progress of particular countries, should stimulate the Union's cultural strategy. According to P. Kern: "[...] The legislature should also take care of the political and institutional support for the idea of creativity and cultural cooperation. Europe has become the dominant economic force in the world due to the fact that the Europeans have competed among themselves as to which of the cultures will gain the upper hand. In the era of globalization, Europe has to compete with the rest of the world in a different way. Since our continent combines a variety of cultures and languages, the European countries need to cooperate to promote diversity and prevent the marginalization of less common languages and cultural expressions" (Kern, 2011: 69). He postulates that through consolidation of actions to strengthen plurality of cultures, Member States enhance the vision of Europe as a creative continent. That's why a redefinition of the EU's strategic goals in the field of culture is necessary, and should not pertain only to the protection of cultural legacy but ensure access to European culture and stimulate tourism. In present progressive conditions it is necessary to define these goals in. The current model for creative progress has led to a "cultural sector that went from a suburbia of economy to its downtown" (Hutter, 2011: 47). Moreover, culture should be treated as important for the Union's further development. This is a key issue related to the co-existence of multicultural societies connected by market regulations. The European integration, characterized by openness to cultural plurality, is at the same time an argument guaranteeing cultural independence of national societies. In such conditions, excluding external "non-European" guarantees protection of culture, which becomes main goal of the Union's cultural strategy, but also raising questions about cultural fundamentalism. Aren't conditions of cultural plurality causing external conflicts, if cultures can be ambivalent and can cause obvious antagonisms? According to V. Stolcke, cultural fundamentalism classifies cultures by geographical location. Undoubtedly the European Union can be so defined (Stolcke, 2011: 275). Obviously, national cultural independence takes priority. Immigration, according to this statement, is a political threat to national integrity and identity. This is explained by the fact that immigrants are, from a cultural point of view, mixed. A country owes its existence to a separate community inside borders, wherein everyone has the feeling of belonging and loyalty based on mutual language, cultural traditions and beliefs. Geographical culture theory loses meaning when facing the progress of digital communications, which is global, universal, and open for every aspect of any culture. This creates a web in which cross-border groups are connected opinions and outlook as expressed in the virtual world. This calls for cultural policy that takes into account the communications and society-forming potential of modern communications. In these certain stances of danger according to web expansion and countries in web must become a part of cultural policy. It concerns fundamentalism, connected with protection of right to privacy, people's dignity and freedom of speech, which are the basis for a democratic country. In the situation of identity crisis, culture becomes the subject of discussion, and cultural happenings are ways to strengthen cultural bonds. It does not only concern the system of value, defined by the European Union, but resulting from the Mediterranean traditions and the Christian ethics. It is a zone of multicultural identities of particular national countries. Considering this problem in a straightforward manner raises the problem of each country's cultural 
independence. The key question is the one concerning which values must be protected. Do these problems concern only high culture, or can it also concern pop-culture? Does it concern the European culture itself, or differentiated cultures, regional, local? In this context, the problem of defining the goals of the European Union's strategy is gaining totally new meaning. It is in this context that efforts to shape the European cultural policy should be framed.

\section{DEBATES $^{2}$}

One of the key events which undoubtedly will influence realization of multicultural dialogue, was the European Congress of Culture.

The Congress, held over four days in Wroclaw, gathered leaders of different environments connected with culture, starting with artists, theoreticians, cultural experts and those from other disciplines such as science, as well as representatives of public administration, European institutions and non-government organizations. Altogether there were 13 debates and many meetings with intellectuals from Europe and from around the world. More than 100 inter-disciplinary projects were presented and in which 500 representatives from a wide range of cultural backgrounds participated. Nearly 100 non-governmental organizations helped prepare the Congress, which accredited more than 15,000 participants including 430 media representatives from Poland and other countries. More than 5,000 tickets were given away. We assume that in all of congress's events more approximately 200,000 people participated (Informacje dodatkowe, 2011).

During the Congress, meetings were held on such topics as common social determinants as they affect culture. Debates raised issues such culture's effect on the process of social and political change, problems concerning future of intellectual property in digital environments, the economics of culture, cultural openness, cultural "recycling", and the interdisciplinary aspects of culture's association with power. One of the key subjects was the role of Europe towards social changes brought on by globalization. During "Strange Europe" moderator D. Ilić noted that commonly functioning national models, with exception of particular countries (divided by language, different lifestyles), are not equivalent to Europe's social changes. According to D. Ilić one should stop focusing on distinct features of national models but start gaining from mutual experience: "Republicanism in France and multiculturalism in the UK has led essentially to the same result - marginalization and discrimination. In each of the cities chosen by me, I see signs of frustration and insecurity. And each of them focused on their own problems, none of them is able to create a narrative that would put them in a broader context than local. Meanwhile, Europe is in my art of translation - translation experience inherent in local languages on one common dialect." In this meaning of Europe's identity we could speak about European cultural sovereignty, in other words ignoring

2 See: Europejski Kongres Kultury: Debaty (2011), http://archiwum.nina.gov.pl/en/katalog?Filter.CategoryCodenames \%5B0\%5D=europejski-kongres-kultury-debaty\&Filter.Sort=PublishDate\&Filter.Desc=True (6.12.2015). 
national borders but addressing a number of countries in a pluralistic cultural view of Europe. Debate participants noticed the phenomenon of a "culture of avoidance" in which migration leads to the situation where individuals search for emotional safety on foreign territory - where conflict is growing. This is connected to the pluralism of opinions across Europe and the European identity - or the difficult-to-define concept of "Europeanness". According to A. Akšamija, the definition of the Europeans and Europe itself are changing. Debate during these sessions concerned Europe's plurality of cultures, but also an abstract definition of the European culture as that term is used and promoted in discussions about united Europe. Answers to the conundrum of "Europeanness" were sought during a debate entitled "Robot's fairytales". Discussion was about the transformations, which are afoot across all European societies in which technological progress is changing life in all its aspects. This panel discussed the impact of new media on culture and a changing Europe, and pointed out creativity's impotence leading to pessimism, which often blocks cultural initiatives. It also discussed the conception of "universal European identity and European culture" as a characteristic cultural matrix for Europe. At the same time it is important to observe that culture often fuels political and social changes, as several speakers pointed out during the discussion "Culture in Action". During this discussion, speakers referred to the revolutionary actions in Arab countries highlighting the value of European Union support for changes in that part of the world. According to G. Sorman: "European governments now recognize that human rights and democracy in Arab countries must be supported by the European Union. That means by the end of this de-masking fantasies about the 'otherness' of the Orient. The revolutions in the Arab countries have shown that despite cultural differences, we all have common goals, common aspirations that all are important: dignity, freedom, freedom of expression, the right to be different." Obviously social changes and the search for new value systems are highly influenced by the general progress of civilization, and along with it progress of new technologies. G. Sorman pointed out that: "Personal choices and behavior determines our culture, our history and traditions of the country we come from. Yes, it's true, but it also affects us in the time in which we live. What is more, thanks to mobile phones, the internet, television, travel - we are now a lot more citizens of his time than we have ever been before. This, of course, owes much to globalization. Normally we associate globalization with communications, commerce, economics. But globalization means something more: it is like a new civilization, offering citizens a common set of values. And, as we have said, in the name of universal values, people in different countries take to the streets. And they do it at the same time". On the other hand R. Triki pointed out that culture and democracy must always be based on the concept of human dignity. Technological conditions and progress of communication can support plurality of cultures, but can be a threat as well. From among the debates mentioned above, special attention should go to a panel for a session on "Wikianarchy", which refers to problem of copyrights in digital environment. Copyright is subject of many European directives, which introduce minimum protection connected with culture. In the context of ensuring cultural sovereignty this subject, on a European basis, has important meaning in discussion concerning the need for future regulations adequate to digital conditions, recognizing the common usage of Internet in the ongoing process of cultural development. According to R. "Rick" Falkvinge: "The 
Internet is an integral part of society - a tool allowing citizens to exercise their fundamental rights. Anonymous access to the unfiltered and unmonitored internet is as fundamental a right, as the rights that we exercise through it". Copyrights monopolies enables some of enterprises to put their own business ahead of laws aimed at protecting citizens, which is unacceptable in the concept of fundamental rights. According to this expert, business must adapt to the rules defined by society, not the other way around. R. Xalabarder agreed with this statement, saying that the system of copyrights should not protect existing business models, noting that copyright has always been suited to modern technology. On the other hand R. Markiewicz said: "Copyright law is needed because it pursues universal values, however it requires a modification to match the real needs of the information society. We are dealing with a strange kind of property. Whatever you write, it is immediately protected throughout the world by copyright law. And still it should be. Changes that necessitate new terms should apply in the first place, and the possible exception of new licenses that you need to come up with and implement." Discussion was radically summed up by J. Smiers considering bans on usage of creation as threat for democracy, which can result, in the end, in "cultural fossilization". Discussion on the future of copyrights should be about the liberalization of the rules based on individual cultural legacies versus strict supervision over sharing content in a digital world. No doubt this issue will be main subject of discussion on future regulations about culture. The subject of copyrights is a theme on international forums, and is an element of the Union's policy of regulations.

On 9 December 2015 the European Commission unveiled its vision to modernize the EU copyright rules in the document titled Towards a modern, more European copyright framework (Communication, 2015). As announced in the 2016 Commission Work Programme, the Digital Single Market Strategy will be taken forward in the area of copyright with a step-by-step approach.

According to the announcement above as a first step, the Commission adopted a legislative proposal on cross-border portability, which will ensure that subscribers to online content services can continue using them while temporarily present in another Member State. Further measures will follow in 2016, as set out in the Commission Communication. The Commission's action plan is built on four complementary pillars:

- widening online access to content across the EU, including in the light of the results of the review of the Satellite and Cable Directive;

- adapting exceptions to copyright rules to a digital and cross-border environment, focusing in particular on those exceptions and limitations which are key for the functioning of the digital single market and the pursuit of public policy objectives (such as those in the area of education, research - including text and data mining - and access to knowledge);

- creating a fair marketplace, including as regards the role of online intermediaries when they distribute copyright-protected content;

- strengthening the enforcement system.

The EU copyright rules need to be adapted so that all market players and citizens can size the opportunities of this new environment. Digital technology and networks equally facilitate distribution and access to education, research, knowledge and heritage. Modernising the copyright rules "in the light of the digital revolution, new 
consumer behaviour and Europe's cultural diversity" is a clear priority for this Commission and one of the main pillars of the Digital Single Market Strategy. It aims to enable the use of the full potential of digital technology and make sure that copyright remains a driver for creativity and investment.

*** *

Considering the global nature of this subject, it requires special treatment and actions that go beyond national borders, although it also brings up questions about the range of the Unions regulations strictly referring to culture and national culture. We cannot ignore Z. Bauman's "Culture in a Fluid Modern World" which was published in the context of the National Cultural Program of Presidency: "It is globalization which, biting into the sovereignty of national states, breaks the protective wall of territorial independence that for some two centuries secured the national identity. It would crumble the national sovereignty even harder if not for the Union's solidarity" (Bauman, 2011: 91).

A direct consequence of the European Cultural Congress is a petition, "More Culture in the EU Cohesion Policy", which refers to the EU's unity policy plans for the years 2014-2020. Regulations concerning the European Regional Development Fund and European Social Fund address the protection of cultural legacy, however they don't cover issues concerning the progress of cultural enterprise, education in culture and many other tangential areas. When we promote the topic of culture, cultural protection of either nations or "Europeanness", and address threats associated with globalization - this points to the challenges and sets the range of necessary discussion about future regulation and methods of decision-making. Does it concern cultural protection, individually for every country or we can speak about the European cultural protection? Furthermore, if discussion so far leads to the conclusion that a mutual cultural policy should be set, is it time to think about what those policies should be? Is it only cultural enterprise in the context of economics, important for a common market? How critical are issues associated with global changes, which influences international relations - for example the problem of copyrights in a digital world? Should those policies address the role of culture as catalyst for social and political change, perhaps signaled by the motto "we want iPads too?" If we speak about cultural pluralism, this discussion may not take place without considering basic systems of values ruling in particular nations. This concerns tradition, religion, public morality and histories of individual nations. All of these sensitive elements make up culture and that's why every attempt to discuss this subject will continue to be a challenge. Debate on the European cultural policy is only beginning. What specifically will be the subject of these discussions is not yet specified. The European forum issues have only a general character and are just a prelude to key discussions on the subject what European Culture is nowadays. Even if the answer seems obvious, they are cultures of particular Member States, we still will not know if it will be elite or "high culture", or "pop-culture" - the culture of the masses?

The answer may be indirect but it refers to the culture, which we don't know from media, internet, billboards, and banners but the one that we learn by belonging in particular social group, religion, and mainly family. It seems right to bring up words of XII century theologist Hugon: "A man to whom only the homeland is sweet is fragile 
and a beginner; But he to whom every country feels like his homeland is growing in strength. But a man is perfect to whom the whole world is foreign" (Said, 2005: 512).

\section{BIBLIOGRAPHY}

Baumann Z. (2011), Kultura w phynej nowoczesności, Warszawa.

Chahubińska-Jentkiewicz K. (2011), Media audiowizualne. Konflikt regulacyjny w dobie cyfryzacji, Warszawa.

Chahubińska-Jentkiewicz K. (2013), Rzecz a znaczeniu polskiej prezydencji dla bezpieczeństwa kulturowego w Unii Europejskiej. Aspekty prawne, "Zeszyty Naukowe AON", No. 1 (90).

Commission Report to the European Parliament, the Council, the European Economic and Social Committee and the Committee of the Regions on the implementation of the European Agenda for Culture (2010), COM/2010/0390 final, Brussels, 19.07.2010.

Cultural Programme of the Polish Presidency (2011), http://www.mkidn.gov.pl/pages/pl2011/en/gora/ achievements/cultural-programme-of-the-polish-presidency.php?lang=EN (23.04.2016).

Dragicevic-Sesić M., Stojkovic B. (2010), Kultura: zarządzanie, animacja, marketing, Warszawa.

Europejski Kongres Kultury: Debaty (2011), http://archiwum.nina.gov.pl/en/katalog?Filter.CategoryCodenames $\% 5 \mathrm{~B} 0 \% 5 \mathrm{D}=$ =europejski-kongres-kultury-debaty\&Filter.Sort=PublishDate\&Filter.Desc=True $(6.12 .2015)$.

Hutter M. (2011), Kultura w gospodarce ery kreatywności i doznań, in: Ekonomika Kultury. Od teorii do praktyki, (ed.) B. Jung, Warszawa.

Informacje dodatkowe po Kongresie (2011), http://www.culturecongress.eu/static/congress_summary (6.12.2015).

Kern P. (2011), Polityka kulturalna: Nowe trendy w Europie, in: Ekonomika kultury. Od teorii do praktyki, (ed.) B. Jung, Warszawa.

Kitler W., Skrabacz A. (2010), Bezpieczeństwo ludności cywilnej, Warszawa.

Krajowy Program Kulturalny Polskiej Prezydencji (2011), http://www.nina.gov.pl/projekty/krajowypro-gram-kulturalny-polskiej-prezydencji-2011/ (6.12.2015).

Krzemień-Ojak S. (1991), Przyszlość tradycji. Próba prognostycznego ujęcia roli dziedzictwa kulturowego, "Ochrona Zabytków", No. 1.

Said E. (2005), Orientalizm, Poznań.

Stolcke V. (1995), Talking culture: new boundaries, new rhetorics of exclusion, "Current Anthropology", Vol. 36 (1).

The Charter of Fundamental Rights of the European Union (2010), O.J. UE C 83, 30.03.2010.

The Communication from the Commission to the European Parliament, the Council, the European Economic and Social Committee and the Committee of the Regions: Towards a modern, more European copyright framework (2015), $\operatorname{COM(2015)626~final,~9.12.2015.~}$

The Commission Report on multicultural dialogue, for the European Parliament and Council, and for the European Social and Economy Committee of Regions (2010), COM(2010)390 final, 19.07.2010.

The Constitution of the Republic of Poland (1997), O.J. 1997, No. 78, Item 483.

The decision of the European Parliament and the Council 1983/2006/EC European Year of Multicultural Dialogue (2006), O.J. L 412, 30.12.2006.

The European Agenda for Culture \& Work Plan for Culture 2011-2014 (2010), O.J. UE C 325/1, 2.12.2010. 
The resolution of the Council of 16 November 2007 on a European Agenda for Culture (2007), O.J. C 287, 29.11.2007.

The Treaty on European Union and the Treaty on the Functioning of the European Union - Consolidated version of the Treaty on the Functioning of the European Union-Protocols - Annexes - Declarations annexed to the Final Act of the Intergovernmental Conference which adopted the Treaty of Lisbon, signed on 13 December 2007 (2012), O.J. UE C 326, 26.10.2012.

Waever O. (1995), Identity, integration, and security: solving the sovereignty puzzle in EU studies. "Journal of International Affairs", No. 48.

Zeidler K. (2004), Pojeccie "dziedzictwa narodowego" w Konstytucji RP i jego prawna ochrona, "Gdańskie Studia Prawnicze", No. 12.

\begin{abstract}
The debate on European cultural policy has only just begun. What is intended to be the object is unknown. Topics taken during the European Culture Congress have the general nature and are only an introduction to critical reflection on what today is the European culture. Even if the answer seems obvious that these cultures of the Member States, we still do not know whether it will be called. "High culture", remaining in the elite circle of interest, or so. "Pop culture"? Perhaps the answer is indirect, and refers to the culture that we do not know from the media, the internet, billboards and banner ads, but rather that which we know through membership in a particular social group, religious community, and most of all family.
\end{abstract}

Key words: culture, cultural policy, national identity, cultural diversity

\title{
POLITYKA KULTURALNA W UNII EUROPEJSKIEJ: NOWE ZADANIA?
}

\section{STRESZCZENIE}

Debata na temat polityki kulturalnej oraz bezpieczeństwa kulturowego w nowych warunkach cyfrowego komunikowania dopiero się zaczyna. Problematyka ta ma szczególne znaczenie ze względu na procesy globalizacji i indywidualizacji przekazu. Dostęp do dóbr kultury jest coraz łatwiejszy, ale jednocześnie samo pojęcie kultury wymaga redefinicji. Jeśli mówimy o bezpieczeństwie kulturowym, należy zastanowić się co ma podlegać ochronie. Dyskusja ta toczy się przede wszystkim na forum europejskim. Czy mówi się o kulturze w kontekście "kultury wysokiej”, czy raczej powinno się chronić wszelką kulturę powszechnie określaną pojęciem "pop kultury"? Jednocześnie czy można mówić o kulturze europejskiej? Analizując zagadnienie bezpieczeństwa kulturowego należy zastanowić się nad tym, jakie ono ma znaczenie dla bezpieczeństwa narodowego, konkretnego państwa. Artykuł obejmuje analizę aktów europejskich, jako narzędzia realizacji ochrony bezpieczeństwa kulturowego, dotyka kwestii strategii i polityki kulturalnej Unii Europejskiej oraz zawiera wnioski z debat, które miały miejsce podczas Europejskiego Kongresu Kultury we Wrocławiu.

Slowa kluczowe: kultura, bezpieczeństwo kulturowe, polityka kulturalna, tożsamość narodowa, różnorodność kulturowa 